\title{
ArcheoSciences
}

Revue d'archéométrie

33 (suppl.) | 2009

Mémoire du sol, espace des hommes

\section{Integrated GPR and archaeological investigations to characterise the Palatino's area and Coliseum Valley (Forum, Roma, Italy)}

\section{S. Piro and Dean Goodman}

\section{(2) OpenEdition}

\section{Journals}

Electronic version

URL: https://journals.openedition.org/archeosciences/1625

DOI: 10.4000/archeosciences. 1625

ISBN: 978-2-7535-1599-4

ISSN: $2104-3728$

Publisher

Presses universitaires de Rennes

\section{Printed version}

Date of publication: 30 October 2009

Number of pages: 233-235

ISBN: 978-2-7535-0943-6

ISSN: $1960-1360$

\section{Electronic reference}

S. Piro and Dean Goodman, "Integrated GPR and archaeological investigations to characterise the Palatino's area and Coliseum Valley (Forum, Roma, Italy)", ArcheoSciences [Online], 33 (suppl.) | 2009, Online since 30 October 2011, connection on 01 February 2022. URL: http://journals.openedition.org/ archeosciences/1625; DOI: https://doi.org/10.4000/archeosciences.1625 


\title{
Integrated GPR and archaeological investigations to characterise the Palatino's area and Coliseum Valley (Forum, Roma, Italy)
}

\author{
S. Piro* and D. Goodman **
}

Key words: GPR data processing, Palatino Hill Roma, Archaeological excavations.

From 2001 to 2008 a series of archaeological investigations made side-by-side with geophysical surveys at the Palatino Hill and the Coliseum Valley, nearest Elagabalo's Thermae (Forum, Roma), a sequence of complex buildings related to the Roman period between the late republican and Severo's age have been detected. The oldest building is a domus of the late Republican period which is located nearest a tabernae, in front of a line connecting the Coliseum Valley and the Roman Forum. The fire-raising of 64 a.C., signed the destruction of these buildings and the development of Neronian urbanism. The archaeological excavations made subsequent to the GPR surveys, have located a surviving foundation from a portico which would have bordered the way through the Coliseum Valley and Roman Forum, a portion of a sewerage system with S-N direction, and an E-shaped foundation which structurally closes the Elagabalo's Thermae.

GPR surveys were performed during September 2001 employing a SIR $10 \mathrm{~A}^{+}$(GSSI), and during May 2004 using a SIR 3000 (GSSI) equipped with a $500 \mathrm{MHz}$ bistatic antenna with constant offset, at selected areas on the northeast foot of Palatino Hill. GPR surveys were also conducted in areas in the Coliseum valley using a $70 \mathrm{MHz}$ monostatic antenna in November 2002 and 2003 and follow-up surveys as recent as January 2008 were made using the $500 \mathrm{MHz}$ bistatic antenna. All GPR profiles at the two sites were collected alternately in reversed and un-reversed directions across the survey grids. The horizontal spacing between parallel profiles for both antennas at the site was $0.5 \mathrm{~m}$. Radar reflections along the transects were recorded in continuous acquisition mode across the ground at $80 \mathrm{scan} \mathrm{s}^{-1}$; horizontal stacking was set to 4 scans. Along each profile markers were spaced every $1 \mathrm{~m}$ to provide spatial reference.

At several sites on the northeast foot of Palatino's Hill all radar reflections within several penetration time windows of $95 \mathrm{~ns}, 105 \mathrm{~ns}$ and $150 \mathrm{~ns}$ were recorded digitally in the field as 8 bit data and 512 samples per radar scans. All radar reflections at the Coliseum valley site were collected alternately in reversed and un-reversed directions across the survey grids, within the 100 ns and 145 ns within the recorded two-way-travel times.

Some of the data were synthesized using GPRSIM v3.0 simulation software to perform the forward modelling. In this process we use the simulation software in an iterative approach by guessing a model, running the simulation, and then comparing the simulation with a real recorded radargram collected over the site. The beginning subsurface model is continually adjusted till we get a good match between real and synthetic radargrams. GPRSIM uses a $2 \mathrm{D}$ raytrace algorithm and a conductive-dissipative model for EM propagation. The

* Institute of Technologies Applied to Cultural Heritage ITABC-CNR (Rome, Italy). (salvatore.piro@itabc.cnr.it)

** Geophysical Archaeometry Laboratory, 20014 Gypsy Ln, Woodland Hills, CA 91364 USA. (dean@gpr-survey.com) 
simulator incorporates antenna designs including the directional response functions of receiving and transmitting antenna, as well as modelled impulse response functions. Complex dielectric and real conductivities can be input into the material properties. The simulator integrates the attenuation along the raypaths as well as the refraction of wavelets at structural boundaries. The reflection/transmission at model boundaries are also monitored and included in the synthesizing of radar reflections (Goodman, 1994).

With the aim of obtaining a planimetric vision of all the subsurface structures present beneath the site, the time-slice representation technique was applied using all field profiles (Conyers and Goodman, 1997; Goodman et al., 2004, 2007, 2008; Piro et al., 2003, 2008). Time-slices are calculated by creating 2-D horizontal contour maps of the wave energy from a specified time value across parallel profiles, employing GPR-SLICE v6.0 Ground Penetrating Radar Imaging Software (www.gpr-survey.com). Time slice datasets were generated by spatially averaging the squared wave amplitudes of radar reflections in the horizontal as well as the vertical. Background filtering was used to remove line noises that were found to exist in the raw unprocessed images.

Using these spatial averages, interpolated and solid 3D volumes of reflections amplitudes were generated. The results are presented in 3D animation using real time Open GL graphic displays in which isosurface rendering, 3D time slice fence diagram are mixed with the raw filtered radargrams. Using spatially binned and interpolated volumes of radar data shows better continuity in mapping subsurface reflections, which are more useful and provide archaeologist an interpretable form of data presentation, then using simple raw or filtered radargrams as volume elements, Fig. 1.

One of the most useful displays of data is from overlay analysis which an option available in GPR-SLICE software. In this process, the user can choose a range of depths to overlay the relative-strongest-reflectors onto a single map. After the starting and ending time slice depths are chosen, the overlays can be created as an animation dataset. The overlay time slices contain reflections from within various chosen depth ranges, and plots them on a single map. In the cases when continuous archaeological features are at varying depths in the ground, the overlay analysis will accumulate reflections from these different depth ranges and help to create a useful map containing all the relevant reflections.

The results obtained on shallowly buried structures indicate that the plan of portion of buried archaeological structures can be identified and characterised from the GPR time-slices representation, (Piro and Goodman, 2008), Fig. 2 and 3. The location, depth, and size and vertical overlapping of the

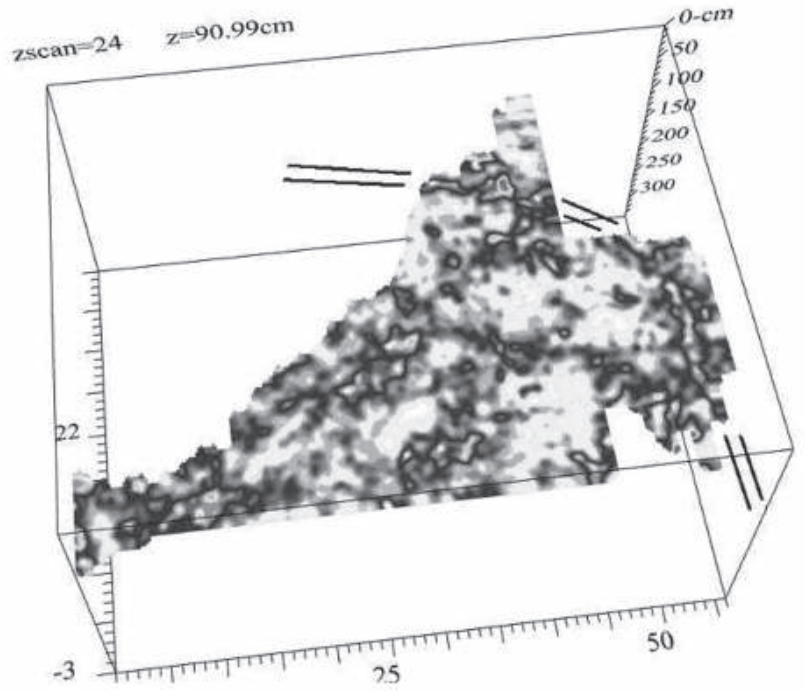

Figure 1: A 3D time slice from the Palatino Hill site is shown at depth at about 1 meter below the ground surface. A wall on the eastern side of the site can be seen at this depth level.

buried buildings were effectively estimated from non-destructive ground remote sensing with a ground-penetrating radar system, together with information on the geomorphology and on the archaeology of the site.

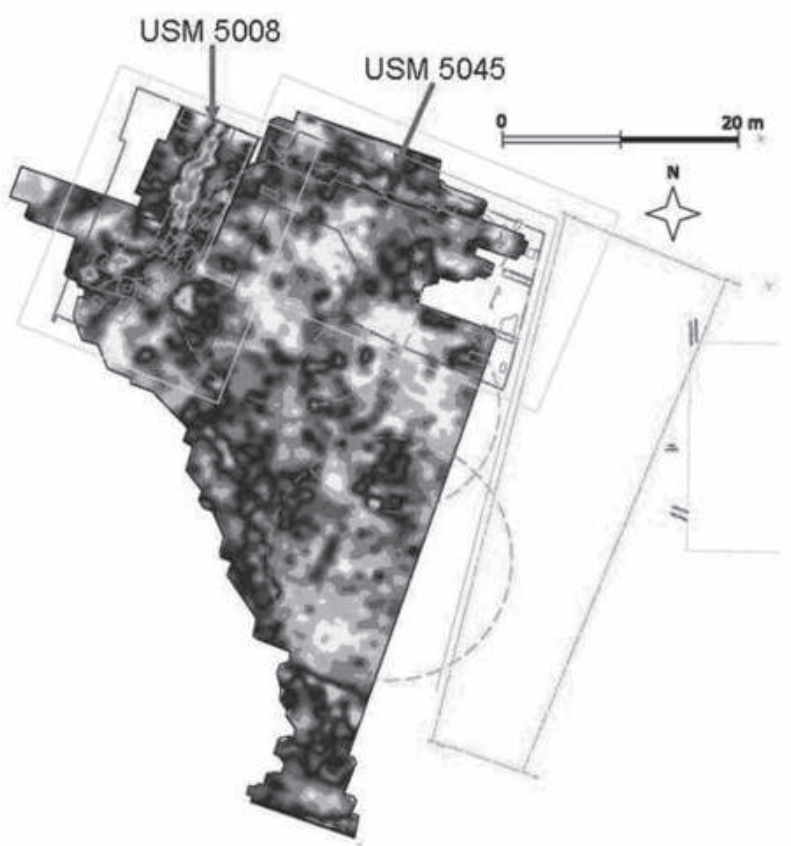

Figure 2: GPR time-slice at a depth of $2.1 \mathrm{~m}$, with an indication of two main walls (USM5008 and USM5045) that have been subsequently verified after the archaeological excavation (violet contour on the map). 


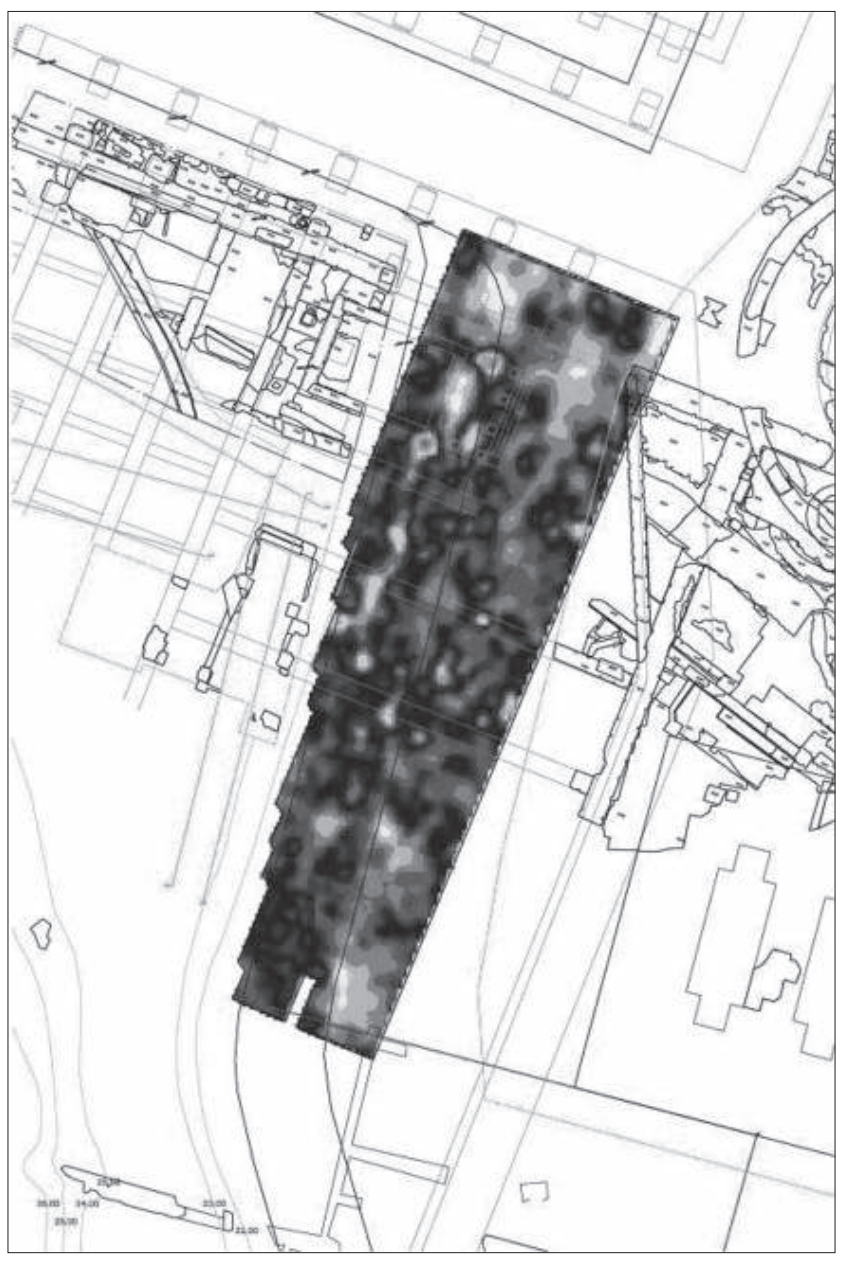

Figure 3: GPR time-slice from the Coliseum Valley at a depth of $3.0 \mathrm{~m}$, overlaid on a map of known and extrapolated archaeological features determined from excavations.

The archaeological excavations made (by Prof. Clementina Panella-Sapienza, University of Roma) during the last years, have confirmed several of the structures delineated with the geophysical methods. This project is still in progress and new surveys are planned to investigate the area between the Coliseum, Costantino's Arc and the Via Sacra at Roman Forum.

\section{ACKNOWLEDGMENTS}

Authors are very grateful to Prof. C. Panella for the fruitful discussion about the archaeological interpretation of the GPR results. Authors thanks also D. Verrecchia (ITABC-CNR) for the help during the GPR surveys.

\section{References}

Conyers, L. B. and Goodman D., 1997. Ground Penetrating Radar. An introduction for archaeologists. AltaMira Press, Walnut Creek, California.

Goodman, D., 1994. Ground-penetrating radar simulation in Engineering and Archaeology. Geophysics, 59:224-232.

Goodman, D., Piro, S., Nishimura, Y., Patterson, H. and GaffNeY, V., 2004. Discovery of a $1^{\text {st }}$ century Roman Amphitheater and Town by GPR. Journal of Environmental and Engineering Geophysics, 9 (1): 35-41.

Goodman, D., Schneider, K., Piro, S., Nishimura, Y. and Pantel, A.G., 2007. Ground Penetrating Radar Advances in Subsurfaces Imaging for Archaeology. In J. Wiseman, F. El-Baz, (dir.). Remote Sensing in Archaeology. Chapter 15, 367-386.

Goodman, D. and PIRo, S., 2008. Ground Penetrating Radar (GPR) surveys at Aiali (Grosseto). In Campana, S., Piro, S., (dir.). Seeing the un-seen. Geophysics and landscape archaeology. Taylor and Francis Group, London, 297-302.

Piro, S., Goodman, D. and Nishimura, Y., 2003. The study and characterisation of Emperor Traiano's Villa (Altopiani di Arcinazzo - Roma) using high-resolution integrated geophysical surveys. Archaeological Prospection, 10: 1-25.

Piro, S. and Goodman, D., 2008. Integrated GPR data processing for archaeological surveys in urban area. The case of Forum (Roma, Italy). 12th International Conference on Ground Penetrating Radar, June 16-19, 2008, Birmingham, UK. Proceedings Extanded Abstract Volume. 